\title{
Dual-Value Driven Parallel Operating Systems and Interrelations of Resources in Social Enterprise
}

\author{
Tzu-Yang Chang ${ }^{1}$, Jersan $\mathrm{Hu}^{2}$ \& Haw Ran Wong ${ }^{1}$ \\ ${ }^{1}$ Graduate Institute of Business Administration, Fu Jen Catholic University, New Taipei City, Taiwan \\ ${ }^{2}$ Department of Business Administration, Fu Jen Catholic University, New Taipei City, Taiwan \\ Correspondence: Tzu-Yang Chang, Graduate Institute of Business Administration, Fu Jen Catholic University, \\ No.510, Zhongzheng Rd., Xinzhuang Dist., New Taipei City 24205, Taiwan (R.O.C.) Tel: 886-922-427-887. \\ E-mail: 070483@mail.fju.edu.tw
}

Received: August 5, 2012 Accepted: September 6, 2012 Online Published: October 24, 2012

doi:10.5539/ijbm.v7n22p86 URL: http://dx.doi.org/10.5539/ijbm.v7n22p86

\begin{abstract}
Social enterprises create both social and commercial value in society, and therefore aspire to two fundamentally different objectives that guide their operations. This dichotomy of vision precipitates in two divergent consequential managerial systems within these organizations. This research focuses on resolving this contradiction in terms of organization management by adopting multiple-cases comparison method on ten Taiwanese social enterprises, and finds that this triple bottom-line approach can be complementary, supportive, or even contradictory, and the two kinds of markets derived from the social value and commercial exchanges should be integrated to construct a more innovative dynamic within the organization.
\end{abstract}

Keywords: social enterprise, social strategy, social technology, social marketing

\section{Introduction}

The transformative effect of globalization has created a globally oriented economy, and the participation of East Asian regional markets in this economic boom has meant that industrial specialization and global configuration has become more prevalent. In addition, the competitive pressures of the knowledge-based workplace have also meant that employment in traditional industries has declined drastically, and high-tech industries have been affected due to fierce competition in the technological sphere and volatility in international markets.

While employees' earnings and benefits have declined, work pressure has intensified; and social wealth distribution has consequently been taxed heavily. To help create social wealth and employment through investment in large corporations, government is more inclined to encourage strategic industries by providing incentives for internal investing such as land, infrastructure, tax breaks, etc. This demand for economic development has the negative side-effect of distorting the usage of social resources, and intensifying the unequal distribution of social wealth ( $\mathrm{Hu} \& \mathrm{Chen}, 2009)$. Even when the government provides relief for disadvantaged groups, they are often short-term stopgap measures, which are incapable of solving the supply gap on social needs caused by imbalances in social structure.

The consequences often seen are suicide in the disadvantaged families, crumbling of remote communities or communities been eroded by commercial interests, or younger generation facing lower income but higher expenses. Although this trend of industrial development may be armed with glamorous economic figures, the actual living standard of the society has not improved; living conditions of marginalized groups have arguably worsened. It can be said that the pervasive nature of economic development has caused significant distortions in society - primarily because of the mentality of putting economic development without taking into account measures to improve social justice.

Market capitalism depends on public resource allocation from the public sector and the economization of private property from the private business sector to meet people's basic needs. Through the market transaction mechanism and self-regulated exchange decisions, the needs are satisfied when a specific price is settled to complete the purchase, under the premise that the buyer is equipped with adequate purchasing power and the seller the requisite supply capacity. The function of a government lies in planning public social resources to make up for those needs that are not met by the private sector through policy making and performing functions 
such as infrastructure construction, public services, social welfare, and the social relief for targeted groups.

However, due to the bureaucracy within the government system, the divergence of opinions in policy formulation and the inertia in government organizations, government agencies are often unable to effectively create, deliver, and adjust, at its discretion, its services that meet individual needs. As a consequence, government is often unable to compete with the private sector when it comes to grasping customers' needs to effectively transform its resources and provide due services. This "government dysfunction" phenomenon exists in vast swathes of the public sector (Weisbrod, 1988; James, 1987).

Where the government has failed to provide for human needs, the society has turned to business, which is equipped with aggressive economic ambitions, to play the role of serving the people to make up for government failure. However, the essence of business is to be profit-oriented, to adopt competitive strategy, and to maximize resource efficiency. Very often business concentrates so heavily on profit generation that its policies lack the spirit of public interest which results in the negligence of the needs of the disadvantaged. In other words, this has caused the predicament of an ill-structured market primarily driven by asymmetric market information (Hansmann, 2003).

Where private businesses are reluctant to step in and government has failed to perform, i.e. where both government and business have become dysfunctional, the society then turns to NPOs, a sector equipped with the ambition of public service yet without the constrains of bureaucracy, hoping they would become the supporting sector to make up the gap of social needs (Frumkin, 2002). Based on their own respective missions, NPOs provide their services to specific issues affecting the community. However, as this form of organization often lacks public resources from the government, as well as capital generated through engaging in profit generating activities, it is necessary that they depend on government subsidies or private fundraising to execute their services. Under the circumstances of being not self-sufficient, their fundraising goals can easily be affected by macroeconomic factors, leading to the phenomenon of "volunteer dysfunction" (Salamon, 1990).

The social system in capitalism designed business activities and market economy as the first line institutions that serve people's needs. This systematic flaw of capitalism in market distribution promoted the entrepreneurial opportunities of another new form of organization (namely, Social Enterprises). To ensure the maximum coverage of social services, the new system is comprised of government, business, NPOs, and social enterprises and is considered to be most effective in satisfying social needs in the long run. Social enterprises particularly receive most attention from the social service institutions. In European countries and in the realm of sociology, therefore arose the thought of a social organization that emphasizes "a for-profit enterprise, i.e. social enterprise, that more actively engages itself in social services (not merely passively through corporate social responsibility) and that aims at providing social value (especially the societal needs beyond profit making)" as a means to directly improve existing societal needs and unsatisfied living care (Tang, Fung, Au, Lee \& Ko, 2008; Heckl, Peche, Aaltonen, \& Stenholm, 2007).

As the unsatisfied needs are caused by the defects of current social system, it has become a more pressing issue to look into social enterprise, a new form of organization that distinguishes itself from NPOs, ordinary business, and government institutions. This study therefore selected the social welfare ventures in Taiwan that serve the under-valued social needs to observe and analyze in depth their managerial system designs, such as strategic goal, market structure, management technologies, and service delivery systems. To serve as the foundational knowledge for future social enterprise management development, this study hopes to give a more robust theoretical deliberation on how strategic thinking and managerial design of this new form of venture fuse the distinct values of fulfilling social needs and commercial performance and the innovative nature of their management systems.

This study adopted case analysis and multiple cases comparison, with the focus on the interrelationships of the two strategic values of social enterprise and the related market, product technology, marketing, and service delivery systems developed by the dual-value respectively, i.e. the interaction and the internal dynamics of organization. Through examining the theory induction of established social enterprise experiences, it is hoped that this study will provide both emerging social enterprises the theoretical guidance necessary, as well as give a practical reference to managers and social entrepreneurs engaged in organizational transition.

\section{Theoretical Background}

Business ventures mainly depend on free market mechanisms to serve social needs, i.e. through transaction, business ventures can trade with members of society to meet the aims of serving the societal needs by the private sector. However, business organization has its own unique for-profit characteristic, which causes value differences when serving the society. Cohen and Winn (2007) thinks that there are four market imperfections: (1) 
inefficient firms; (2) externalities - A firm's action will have impact on others; the impact could be positive or negative. This feature prevents market from accurately reflecting the prices of the products or services; (3) flawed pricing mechanisms - for example, assuming that natural resource is unlimited, market then can accurately reflect its prices; however, the real scenario is that market often underestimates its prices; and (4) information asymmetries. Consequently these market imperfections often lead to market failure.

Through the theory of market economy, Hu \& Chen (2009) further explore the eight business blinds in the supply and demand conditions in traditional economics, which include: unwilling supply market, inability in the buying market, poorly equipped infrastructure market, high price level supply, differentiated supply-demand market, separated supply-demand market, and profit maximization led resource distortion. They also pointed out the defects of modern operation rationales: seeking private capital returns, emphasizing rational operation analysis, stressing financial performance, etc. All these factors contribute to the systemic flaws of unsatisfied social needs.

To ensure social needs are satisfied with the maximum services, the traditional practice of depending on government, business, and NPOs to deliver social service does not conform to the realistic social state of play. The oft-difficult task of delivering social services falls on institutions closer to social life. The hybrid organization evolved from fusing business enterprises and the social sector; the social enterprise, is therefore considered a new system to solve social problems stably and chronically in the future. Social enterprise is a concept stemmed from the 15 member states of the Organization for Economic Co-operation and Development, [OECD] (1999) issued by OECD, social enterprise is defined as any private commercial activities that generate public interest; it is equipped with strategic entrepreneurship to pursue specific economic and specific social benefits and does not target profit maximization.

Most social enterprises in the society nowadays mainly evolved from the NPOs business venture, the socialization of the traditional businesses, or business ventures and start-ups. The NPOs business venture is a social enterprise developed with a different form of organization and different funding source mainly due to the trend of commercialization, avoiding the over dependence by the people they serve, the external competition, and for the stability of financial resources (Dees, 1998). Also, originated by the charitable motive of the established business ventures and the disparate notion of corporate responsibility targeting social interests, quite a few of these ventures started transforming themselves or even developed start-ups from scratch (Meyer and Kirby, 2010). These new organizations developed a new business form evolved from commercial organizations. These changes thus caused the essential transformation of a social institution pursuing its commercial capacity and a commercial institution pursuing social value, leading to the convergence social phenomenon of from the two originally incompatible system values (Katz \& Kahn, 1978).

Through analyzing the act of social entrepreneurship, Christie and Honig (2006) point out that social entrepreneurship should include the ability to identify opportunity and assemble the necessary resources to meet the unsatisfied or unable to satisfy needs. The Institute for Social Entrepreneurs believes that social entrepreneurship is creating revenues by means of business management approaches to pursue social objectives. Austin, Stevenson, \& Wei-Skillern (2006) consider social entrepreneurship an activity of social innovation that can exist in non-profit, business, or government sectors. The latter brings forward a more broadly encompassing perspective by taking value innovation and creation at its core, stepping outside the framework of adopting business operation measures.

The social enterprises in Taiwan may still be in early stages; however according to the current research, Kuan (2006) concluded the reasons why it has been gaining popularity as follows: responding to social needs; NPOs seeking financial independence; privatization of social welfare and exchange system of social service; government incentives and subsidies; and businesses' valuing social responsibility.

The expectations on social enterprises outlined in the above mentioned definitions all emphasized abstract descriptions like creating social benefits, solving social problems, reaching social targets, etc. They fell short on observing business perceptions or business languages to explicitly assert the missions and the targets of social enterprises. Based on the market supply and demand theories, Hu and Chen (2009) then proposed eight mission targets for social enterprises, aiming at creating as much as possible the provisions that traditional supply-demand or unwilling-supply failed to meet the demand level. They are:

Task 1 To enrich disadvantaged consumers;

Task 2 To motivate unwilling supply;

Task 3 Supply a market with poor infrastructure; 
Task 4 Supply of comprehensive values mix;

Task 5 Supply for differentiated markets demand;

Task 6 To match the gap of supply-demand;

Task 7 Enhance the target of non-financial value;

Task 8 Effectiveness of resource utility.

Listing the missions that emphasize the demand-fulfilling of the disadvantaged help social enterprises more effectively define their operation directions and targets. The social value for social enterprise comes with a distinguished feature of non-economic demand. If this type of enterprise is to fulfill its non-economic targets by means of economic measures, it is most probable that it needs to clearly distinguish its economic and non-economic needs. Through mutual support or shared resources or profit, it may then reach the essentially contradictory goals to truly demonstrate this dual-value driven operating system and its interrelationship.

\section{Research Methods}

\subsection{Sample Characteristics and Features}

The United Kingdom is one of the pioneer countries in promoting social enterprises. Social enterprises are said to be equipped with three distinctive features: social orientation, social goal, and social ownership (Shaw, 2004). In this context, the wide ranging characteristics shared by social enterprises in the U.K. include: (1) exist in response to a need not supported by the market, (2) operate on an NPO basis, (3) profit not distributed to owner but to the community, (4) goods with a clear social, ethical or environmental purpose, (5) hold their assets in trust for the community, (6) incorporate a collective form of accountability and control, (7) have a distinctive local focus, (8) achieve goals by engaging in trading and income generation, (9) entrepreneurial in outlook and looking for innovative solution, and (10) improve the quality of life of employees and community (Social Enterprise London, 2007).

Mair \& Marti (2006) believed social enterprises can be classified into three categories: first, social enterprises are simply fundraising strategies of traditional NPOs, or firms with a management framework aiming at creating social value (Austin, Stevenson \& Wei-Skillern, 2006); second, as a partnership project between for-profit and non-profit divisions in regular businesses to fulfill its social responsibilities (Sagawa \& Segal, 2000); and third as a means to ease social problems or catalyze social transformation (Alvord, Brown \& Letts 2004). Wharton School (2010) pointed out four types of established businesses involved in social entrepreneurship: the training or employing of the disadvantaged, production with affordable prices or provision of products/services of necessity, reasonable loans of easy access for the disadvantaged, and assistance in the provision of skills or raw material.

After examining select firms' founding rationales, socialization process, and entrepreneurship philosophy, this research found that social enterprises are equipped with the following traits, which can be described as the organization-genre dimensions. The correlation matrix in Figure 1 displaying two dimensions of entrepreneur originality and entrepreneurship approach.

\section{Dimension 1: Essence of entrepreneurship: business essence/social essence}

The meaning of social value for social enterprises must be defined from the view of the participants. Defourny (2001) asserted that essentially social enterprise is an organization genre that involves civil participation. When social enterprise is classified by the nature of its original organization and entrepreneurship approaches, according to the hybrid spectrum of Alter (2004), the background of the entity managing social enterprises or the originating institutions that later transformed into social enterprises includes both commercial organizations that pursue economic benefits and operation efficiency and non-profit organizations that emphasize social service and a philanthropic mission.

$\mathrm{Hu}$ and Chang (2009) found that the both business-genre organizations involved in social enterprise and NPO-genre managers involved in entrepreneurship uphold diverse values and technology application. It takes much more rigorous mutual learning to integrate. Therefore, Dimension 1 includes the founders of the organization, its participants, and the entrepreneurship philosophy espoused by the organization.

Dimension 2: Entrepreneurship development: organization/transformation

Dees (1998) believes that a social entrepreneur is an agent of social change, who must identify and seek market opportunities to serve society. Mair and Marti (2006) also point out that discovering social needs is a capacity necessary of a social entrepreneur. Therefore, a social entrepreneur's a priori knowledge, personal experience, 
and the interactions with the stakeholders all have a profound impact on the targeted social value of the social enterprise.

Peredo and McLean (2006) concluded the following features for the concepts of social enterprise: It is an individual or a group of people engaging in: (1) creating social value by exercising brilliant methods and their combination; (2) recognizing and exploiting opportunities to create social value; (3) practicing innovation; (4) accepting and tolerating risk; and (5) at the same time, not being intimidated by the limited resources. Zahra, Gedajlovic, Neubaum \& Shulman (2009) also believed social enterprise is an action and process of identifying, defining, and exploiting opportunity; it is to exercise innovation to strengthen social wealth through new ventures or existed organizations. Dimension 2 then includes the elements like action and process in the course of socialization.

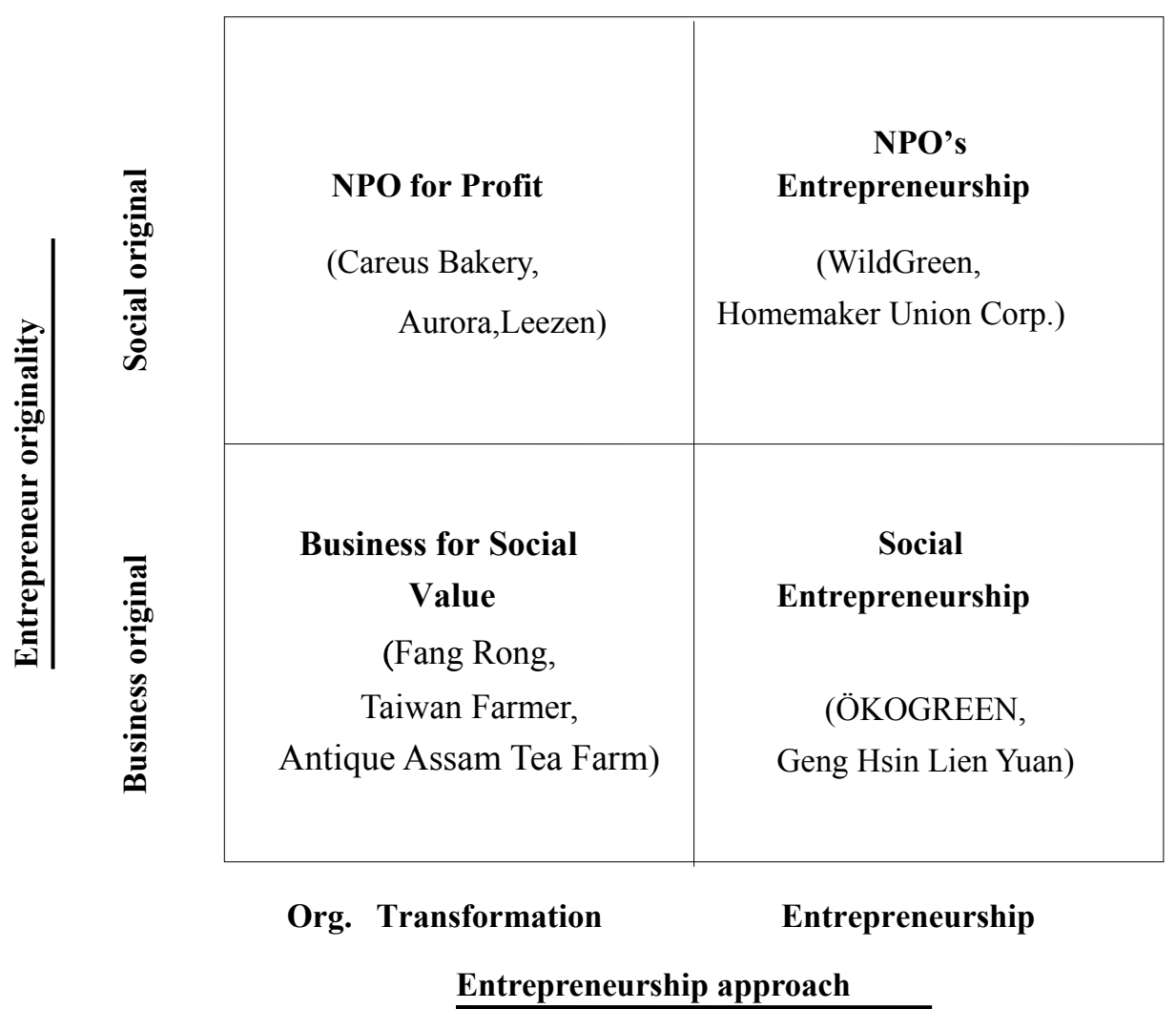

Figure 1. The essence and entrepreneurship of social enterprise

This research studied established social enterprises which take the form of micro-commercial institutions in Taiwan, while excluding internal commercial activities or business ventures of NPOs, e.g. the running of gas stations, cafe, visual design center, and shelter workshop for Victory Development Center; the on-line business of Taiwan Foundation for the Blind; the government sponsored shelter workshop; the cultural organizations, community development association under multiple employment scheme; or self-initiated community care center, e.g. Hebron Development Center. This research studied ten commercialoperations (as seen in Table1) with significant social impact and value contribution, and observed, analyzed and compared their originality, business types, social value, social technology, and social managerial behavior, hoping to learn from them and put together a comprehensive framework describing the development of social enterprise in Taiwan. 
Table 1. The background, service target, and product features of the examined social enterprises

\begin{tabular}{|c|c|c|c|}
\hline Case Firms & Manager Background & Social Benefits & Major Business Items \\
\hline Taiwan Farmer & (young) farmers & $\begin{array}{l}\text { Ecology conservation and } \\
\text { education }\end{array}$ & $\begin{array}{l}\text { Produce manufacturing, sales, } \\
\text { guided eco-tour }\end{array}$ \\
\hline $\begin{array}{l}\text { Fang Rong } \\
\text { Rice Factory }\end{array}$ & Rice mill & $\begin{array}{l}\text { Cohesiveness } \\
\text { economy for aging farm } \\
\text { communities }\end{array}$ & $\begin{array}{l}\text { Growing and sales of quality } \\
\text { brand } \\
\text { community tour, recreation, and } \\
\text { vintage economic activities }\end{array}$ \\
\hline $\begin{array}{l}\text { Antique Assam } \\
\text { Tea Farm }\end{array}$ & Senior business manager & $\begin{array}{l}\text { Eco-agriculture and life } \\
\text { education }\end{array}$ & $\begin{array}{l}\text { Sale of organic tea and related } \\
\text { produce/transform traditional } \\
\text { business, guided tour of organic } \\
\text { agriculture and guided eco-tour }\end{array}$ \\
\hline WildGreen & Retired IT engineer & Organic concept promotion & $\begin{array}{l}\text { Manufacturing and sale of organic } \\
\text { textile/organic life style concept } \\
\text { promotion }\end{array}$ \\
\hline ÖKOGREEN & Int'l fair trade worker & $\begin{array}{l}\text { Establishment of global } \\
\text { fair trade system }\end{array}$ & $\begin{array}{l}\text { Café and related product sale/ } \\
\text { Promotion of fair trade concept }\end{array}$ \\
\hline $\begin{array}{l}\text { Careus Bakery } \\
\text { (restaurant) }\end{array}$ & $\begin{array}{l}\text { Children ARE Us } \\
\text { Foundation }\end{array}$ & $\begin{array}{l}\text { Vocational training and } \\
\text { social inclusion for the } \\
\text { disadvantaged children } \\
\text { (intellectually disabled) }\end{array}$ & $\begin{array}{l}\text { Confectionery production and sale } \\
\text { and restaurants/foster } \\
\text { intellectually disabled children } \\
\text { and change social cognition }\end{array}$ \\
\hline $\begin{array}{l}\text { Geng Hsin } \\
\text { Lien Yuan } \\
\text { Foundation }\end{array}$ & $\begin{array}{l}\text { Education Foundation; } \\
\text { education workers }\end{array}$ & $\begin{array}{l}\text { Community child care and } \\
\text { moral education }\end{array}$ & $\begin{array}{l}\text { Child care, vegetarian restaurant/ } \\
\text { Home foods processing } \\
\text { community parenting }\end{array}$ \\
\hline $\begin{array}{l}\text { Aurora Social } \\
\text { Enterprise } \\
\text { Company }\end{array}$ & $\begin{array}{l}\text { Manna Organic Life } \\
\text { Association (Catholic } \\
\text { indigenous service group) }\end{array}$ & $\begin{array}{l}\text { Life quality of the } \\
\text { indigenous communities in } \\
\text { Mt. Ali }\end{array}$ & $\begin{array}{l}\text { Organic vegetable farming and } \\
\text { group sale }\end{array}$ \\
\hline $\begin{array}{l}\text { Leezen Organic } \\
\text { Chain }\end{array}$ & $\begin{array}{l}\text { Blisswisdom Foundation } \\
\text { (religious group) }\end{array}$ & $\begin{array}{l}\text { Concept dissemination / } \\
\text { ideal practice }\end{array}$ & $\begin{array}{l}\text { Transforming religious belief into } \\
\text { lifestyle and products for } \\
\text { consumption }\end{array}$ \\
\hline $\begin{array}{l}\text { Homemaker } \\
\text { Union Corp. }\end{array}$ & $\begin{array}{l}\text { Co-ops of matching } \\
\text { believes }\end{array}$ & $\begin{array}{l}\text { Group power created } \\
\text { demand scale and formed } \\
\text { sub-market }\end{array}$ & $\begin{array}{l}\text { Concept dissemination/ Collect } \\
\text { market demand }\end{array}$ \\
\hline
\end{tabular}

Source: $\quad$ www.taiwanfarmer.com.tw (Taiwan Farmer); www.afa.gov.tw (Fang Rong Rice Factory); www.assamfarm.com.tw (Antique Assam Tea Farm); www.wildgreen.tw (WildGreen); www.okogreen.com.tw (ÖKOGREEN); www.careus.org.tw (Careus Bakery); www.amtb-gx.org.tw (Geng Hsin Lien Yuan Foundation); www.o-power.com.tw (Aurora Social Enterprise Company); www.leezen.com.tw (Leezen Organic Chain); www.hucc-coop.tw (Homemaker Union Corp)

\subsection{Research Phenomenon}

What differentiates a social enterprise from a regular business is the diversity of their organizational goals. Regular businesses, regardless of the quality difference of their members, the technological features of the industry, the organization scale, and nature of resource, etc., all have common business goals, i.e. resource efficiency or profit maximization. They also have the same target indicators: financial quantitative performance. Therefore, it is easy for them to find common language and to find a basis of comparison in operations, value judgment, and in standards for maneuvering resources. On the contrary, as social enterprise upholds its value in serving the society, any tasks beyond profit generation, ranging from unwilling supply (due to a social demand without chance for profits,) incapability of government (insufficient and untimely provision due to rigid social welfare policy), or demands that volunteer groups cannot meet, will resort to social enterprises for long term provision. 
Given this environment, the conditions these organizations face, including difficulties in resolving particular social problems, the background and personal conviction of the entrepreneurs and the staff within social enterprises, and the amount of resources under ownership, etc. all affect managerial decisions that these social enterprises need to make, including proper understanding of social problems to be solved, marketing, and resource allocation.

In view of the above mentioned conflicts between social value and commercial value and also conflicts in professional skills and motivation, this article aims to articulate the practice of drawing up social and commercial goals, the various features of the target markets, product features serving respective markets, and its production, supply, and distribution. Through discovering the interrelationship of these types of activities, this research hopes to construct a practical approach for social enterprises when resolving value conflicts.

\subsection{Data Collection}

Based on presentations made by the ten different social enterprises examined, interviews with the respective managing directors, field surveys to Antique Assam Tea Farm, Aurora Social Enterprise Company, Leezen Organic Chain, Geng Hsin Lien Yuan Foundation, and the archive of internet information on the case firms, the researchers had access to in-depth discussions with the managing directors to obtain the valuable information, such as the founding missions, commercial operation and social service vision, organizational problems and the process of their solution, etc. This approach of combining first-hand research with available data enriched the study with deep insights on related strategies and operation approaches in their commercial operations as well as social service.

From understanding the comprehensive operational logic of the case firms, this research is then able to grasp the interrelationship between social value creation and typical behaviors of a commercial operation.

\section{Dual-value Driven Parallel Operating Systems}

Austin et al. (2006) think that social enterprise's output type, customer service, trading conditions, and performance evaluation differ itself from commercial entrepreneurship. A social entrepreneur must provide more diverse and heterogeneous value output to inspire and satisfy the motivation of staff from different backgrounds. However, most beneficiaries and consumers of social products are marginalized people without sufficient funds to promote the commercial style market mechanism; therefore, it is imperative to prevent the manager from valuing the preference of the financer and neglecting the needs of the disadvantaged customers they set out to serve.

Also, most social enterprises experience limited venture capital sources and lower financing flexibility (Letts, Grossman \& Ryan, 1999) which often mean that managers are preoccupied with fundraising matters and neglect effective business management and harnessing technology. This contradictory dynamic between social enterprise's social value and economic value is best illustrated with the decision-making processes within these social enterprises.

In view of the need for social enterprises to break away from the institutional operation of traditional NPOs, while at the same time, be equipped with management concepts different from regular commercial settings, innovative design is necessary to reconcile the contradictions. Dees (2001) pointed out that the innovation social enterprises involved in can therefore be considered Schumpeterian innovation a la "creative destruction". Schumpeter (1934) classified this innovation into (1) product or service innovation, (2) new operation mode induction, (3) new market development, (4) new resource introduction, and (5) new industrial organization establishment.

To sum up, the management focus of social enterprises must stress the adjustments in product innovation, value delivery operation, market development, strategies and organizational structure, etc. This research aims to explore the inter-relations of this dual-value system from the perspectives of strategy, organization dynamics, marketing, technology development and value delivery.

\subsection{Business Organizations with Dual-Target Value}

A. Commercial profits supporting social service --- The social purpose of these ventures, e.g. Taiwan Farmer, Fang Rong Rice Factory, WildGreen, Aurora Social Enterprise Company, Homemaker Union Corp., depends on the financial returns from its commercial outputs to carry out its social beliefs.

B. Social value driving commercial operations --- The social value of the original investing institutions or social entrepreneurs can help the firms build its social image or popularity, which in turn boost the product value of its commercial sector or introduction of firm resource to enhance its operation capacity. These firms include: 


\section{Antique Assam Tea Farm, ÖKOGREEN, Careus Bakery, Leezen Organic Chain.}

Guclu, Dees \& Anderson (2002) consider the purpose of social entrepreneurship as realizing the philanthropic social impact as the core of social enterprise development. Social entrepreneurs define its target value through its strategic objectives, design the protocol of reaching the goals, and form a set of operating systems to accomplish its social impact. This relationship lies not only as the fundamental principles of social enterprise but also in the operating system of organization credibility. Alter (2004) and Emerson \& Bonni (2003) have proposed the concept of "Double Value" or "Blended Value" to address this relationship. Through their work, they have not only modified the profit perspective of the "double bottom line" towards a value perspective, but have also stressed blended value as "one" dual-target value.

Proposition 1: Social enterprises, upholding non-economic social value target and economic commercial profit target, due to the diversity of these two-fold targets, create within the organizations a dual-target value oriented operation system.

\subsection{The Interrelationship between Commercial Customers and Social Customers}

The commercial product a social enterprise offers is of different concept from the social targets it intends to serve. In practice, these two target markets are related in the following forms:

A. Common market--- The groups, e.g. Homemaker Union Corp., Leezen, Geng Hsin Lien Yuan Foundation, etc. provide target social groups with the specific products they need to meet the intended social value. In this sense, the commercial products social enterprises provide must be particularly designed to meet the needs of the social customers they serve. Therefore, the relationship between the two target markets is superimposed.

B. Connected markets--- Social customers as the front-end producers while commercial customers as the rear-end consumers. Through this type of marketing relationship, it is possible to help social customers create commercial interests and employment, e.g. Aurora Social Enterprise Company, Taiwan Farmer, Fang Rong Rice Factory, etc. At this point, the two target markets are vertically interrelated.

C. Idea Markets--- Through commercial consuming process, this type of firms promote the social value they uphold; therefore, their non-specific customers constitute their social market. Often, this type of firms emphasizes the promotion of particular social value, e.g. "fair trade" of ÖKOGREEN, "organic apparel" of WildGreen, "Children are Us" of Careus Bakery, "Life Education" of Antique Assam Tea Farm. They all promote social value through commercial activities and form the relationship of ideas between the two target markets.

Budinich, Reott \& Schmidt (2009) pointed out three important principles for the market-based social innovation: (1) design the products/services which meet the needs of the poor, guiding the product technology development of social enterprises; (2) change the value logic of current operation mode, emphasizing the social enterprises' internal operation philosophy and strategic goal decision, i.e. the strategy change of social enterprise; (3) consider the target groups it serves as producers and consumers, involving in the marketing innovation in social market and commercial market.

Proposition 2: The social value goal of a social enterprise guides the organization in searching for social markets; by the same token, the economic goal guides the organization in searching for commercial markets. The overlapping of various degrees exists in these two types of markets; it includes: complete overlap, vertical correlation, and shared ideas, etc.

\subsection{Technical Relationship between Commercial Products and Social Products}

The consuming products that social enterprises provide to commercial markets often are different, in form and in meaning, from the social products offered to social customers. However, limited to the market relationship as mentioned above, the design concepts for these two types of products must be interrelated. Their relationships are as follows:

A. Product line extension--- Commercial products share the same technological essence as social products; however, they do differentiate in their field of application. For example, Taiwan Farmer business is based on the agricultural production and marketing of certain regions and further extends it to the ecology education navigation and maintenance of the unique local geology landscape. Others like Antique Assam Tea Farm and Geng Hsin Lien Yuan also possess this product line extension relationship.

B. Forward integration of value--- Commercial products emphasizes the development of product technology; at the same time, a firm attaches social value and ideology to them to develop marketing technology for social marketing and help the firm to disseminate the value it upholds to promote social awareness. Examples are 
WildGreen, ÖKOGREEN, and Aurora, etc.

C. Backward integration of value --- Some specific groups with products serving daily needs which can't be satisfied by the market would need to go backward to integrate, cultivate, or control the commercial system that satisfy their commercial motives. Examples are: Homemaker Union Corp., Leezen, etc.

D. Product diversification --- The actualization of original social ideas needs the creation of commercial products of diversified functions. The new products stemming from commercial product technology constitute diversified product lines. For example, Fang Rong Rice Factory began with organic farming through the rice farmer, and then moved on to promote community-specific culture through rice branding; Careus Bakery started by providing employment and a channel to integrate mentally impaired people in society, and then moved on to the operation of diners and even farms for them.

Entrepreneurship is a major means of solving the market imperfections and failures. Shane and Venkataraman (2000) stress the importance of entrepreneurship to address market imperfections in the following manner: (1) entrepreneurship is a mechanism that transforms the society's technology information into products and services; (2) entrepreneurship is a mechanism which discovers and mitigates the inefficiency (temporal and spatial) of an economy; (3) entrepreneurship drives the innovation of products and processes and is the engine driving the change process.

Proposition 3: Social enterprises design social products to satisfy the social needs in the social market. By the same token, they design the commercial products to satisfy the consumption needs in the commercial market. The interrelationships existing in these two kinds of products are: product line extension, forward integration of value, backward integration of value, and product diversification.

\subsection{The Operational Relationship between Business Process and Social Process}

Commercial products first need the operators' strategic guidance; then through the upstream product design and manufacturing and the downstream product distribution and services, the product value in the consuming activities can be delivered. When social enterprises intend to deliver social value beyond product value, the inevitable problem they face is how to design the manufacture and delivery processes which combine both values.

A. Vertical combination--- Product process and social process maintain a compatible vertical operation relationship

A1. Forward integration of business process --- Taiwan Farmers has in the front end the production of agricultural produce and marketing process; then through promoting the eco-tour of the farmland, it simultaneously disseminates information on agricultural ecology and drives produce sales; commercial process hence has a vertical blending with social process. The same practice can be seen at ÖKOGREEN which also is an actualization of commercial process propelling their unique social concept.

A2. Backward integration of business process --- Antique Assam Tea Farm, WildGreen, Aurora, and Leezen first have their social concepts established to propel their commercial process or find their markets.

B. Joint Process--- In their commercial processes, Careus Bakery and Geng Hsin Lien Yuan not only create the consumption value of their commercial products, but also deliver the concept of social value. The production of both values share the same operational process.

C. Separated Process--- The commercial production processes of Fang Rong Rice Factory and Leezen is isolated from the social production processes; each can function independently without the other.

A research on the management pattern of social enterprises by Mair \& Schoen (2007) showed that social entrepreneurs not only search for their positioning in the industry value chain from the commercial perspective, but should plan ahead the business network which shares their social enterprises' visions.

Proposition 4: Social products must be equipped with the social process that can form and deliver social value. By the same token, commercial products must be equipped with the commercial process that can form and deliver commercial value. Different forms of interactive relationship exist between social process and commercial process. They include: vertical blending, forward and backward integration of business processes, joint process, and separated process, etc.

\subsection{Organization Dynamics Enhanced by Commercial Value and Social Value}

In the operation of commercial value and social value, as certain degree of interactions exists respectively among target customers, product technology, and value process, it shows that interactions should also exist in the 
commercial value and social value created by social enterprises. Table 2 provides an overview of ten cases in terms of regarding commercial and social values, technologies, and processes.

After enterprising NPOs transform into social enterprises in order to differentiate themselves from the operational behavior of NPOs and introduce management concepts and technology capacity, it becomes necessary for NPOs to adjust their management strategies and organization structures (Dees, 2007). In other words, social enterprises espousing economic value, and bringing social value to the original business constitution, creates pressure on NPOs to drive for organizational change in their internal constitution. These pressures manifest themselves during the formational phase of social enterprise, as differences exist between the concepts and value judgment of these two contradictory value systems. Therefore, these changes require the processes of mutual learning and knowledge innovation to color the creation of a new organization structure (Hu \& Chang, 2009).

Table 2. The comparison of social enterprises' commercial and social values, technologies, and processes

\begin{tabular}{|c|c|c|c|c|c|c|}
\hline Case Firms & Products & $\begin{array}{l}\text { Target } \\
\text { Customers }\end{array}$ & Social Benefits & SocialTarget & Social Process & $\begin{array}{l}\text { Commercial and Social } \\
\text { Interaction }\end{array}$ \\
\hline $\begin{array}{l}\text { Taiwan } \\
\text { Farmer }\end{array}$ & $\begin{array}{l}\text { Produce } \\
\text { production and } \\
\text { marketing }\end{array}$ & Households & $\begin{array}{l}\text { Land ecology } \\
\text { maintenance }\end{array}$ & $\begin{array}{l}\text { Community } \\
\text { landowner (suppliers) } \\
\text { / (consumers) } \\
\text { eco-education }\end{array}$ & $\begin{array}{l}\text { (Commercial) Produce production } \\
\text { and sales; } \\
\text { (Social) eco-tour, land } \\
\text { eco-maintenance }\end{array}$ & $\begin{array}{l}\text { Commercial profits } \\
\text { support social service }\end{array}$ \\
\hline $\begin{array}{l}\text { Fang Rong } \\
\text { Rice Factory }\end{array}$ & $\begin{array}{l}\text { Quality rice } \\
\text { production and } \\
\text { y sales; community } \\
\text { cultural tour }\end{array}$ & Households & $\begin{array}{l}\text { Community } \\
\text { economic } \\
\text { activities planning } \\
\text { and marketing }\end{array}$ & $\begin{array}{l}\text { Farmers, community } \\
\text { shops }\end{array}$ & $\begin{array}{l}\text { (Social) Awareness building - } \\
\text { organic farming; } \\
\text { (Commercial) branding, community } \\
\text { economy planning }\end{array}$ & $\begin{array}{l}\text { Promoting commercial } \\
\text { activities through } \\
\text { exercising social } \\
\text { connections }\end{array}$ \\
\hline $\begin{array}{l}\text { Antique } \\
\text { Assam Tea } \\
\text { Farm }\end{array}$ & $\begin{array}{l}\text { Tea and } \\
\text { by-product } \\
\text { Sales and } \\
\text { Tea-making } \\
\text { intro. }\end{array}$ & Households & $\begin{array}{l}\text { Land } \\
\text { conservation, } \\
\text { Life education }\end{array}$ & General public & $\begin{array}{l}\text { (Social) Tea making tour, Tea farm } \\
\text { guided tour; } \\
\text { (Commercial) Sale of tea }\end{array}$ & $\begin{array}{l}\text { Parallel operation of } \\
\text { commercial activities } \\
\text { and social education; } \\
\text { social education } \\
\text { out-values commercial } \\
\text { activities }\end{array}$ \\
\hline WildGreen & $\begin{array}{l}\text { Organic } \\
\text { garment } \\
\text { production and } \\
\text { sales }\end{array}$ & Households & $\begin{array}{l}\text { Organic } \\
\text { consuming } \\
\text { concept }\end{array}$ & $\begin{array}{l}\text { Public; Organic cotton } \\
\text { production chain }\end{array}$ & $\begin{array}{l}\text { (Social) Organic ecology concept } \\
\text { education; } \\
\text { (Commercial) Product design, } \\
\text { consigned production, and brand } \\
\text { marketing }\end{array}$ & $\begin{array}{l}\text { Parallel operation of } \\
\text { commercial activities } \\
\text { and social education; } \\
\text { social education } \\
\text { facilitates commercial } \\
\text { activities }\end{array}$ \\
\hline $\begin{array}{l}\text { ÖKOGREE } \\
\mathrm{N}\end{array}$ & $\begin{array}{l}\text { Café, coffee, } \\
\text { coffee maker } \\
\text { and others }\end{array}$ & Households & $\begin{array}{l}\text { Support world } \\
\text { Fair Trade practice }\end{array}$ & $\begin{array}{l}\text { Farmers (under Fair } \\
\text { Trade) }\end{array}$ & $\begin{array}{l}\text { (Commercial) Coffee sales; } \\
\text { (Social) Promoting Fair Trade } \\
\text { concept }\end{array}$ & $\begin{array}{l}\text { Parallel operation of } \\
\text { commercial activities and } \\
\text { social education; social } \\
\text { activities out-valued the } \\
\text { commercial one }\end{array}$ \\
\hline $\begin{array}{l}\text { Careus } \\
\text { Bakery } \\
\text { (Restaurant) }\end{array}$ & $\begin{array}{l}\text { Baked goods; } \\
\text { restaurant }\end{array}$ & Households & $\begin{array}{l}\text { Work skills and } \\
\text { social inclusion } \\
\text { for the mentally } \\
\text { impaired youths }\end{array}$ & $\begin{array}{l}\text { Mentally impaired } \\
\text { youths }\end{array}$ & $\begin{array}{l}\text { (Commercial and Social complete } \\
\text { inclusion) Work skill education and } \\
\text { product making; sales coaching }\end{array}$ & $\begin{array}{l}\text { Through commercial } \\
\text { activities (means) to } \\
\text { change societal concept } \\
\text { (target) }\end{array}$ \\
\hline $\begin{array}{l}\text { Geng Hsin } \\
\text { Lien Yuan } \\
\text { Foundation }\end{array}$ & $\begin{array}{l}\text { Day care; } \\
\text { restaurant; } \\
\text { hand-made } \\
\text { foods }\end{array}$ & $\begin{array}{l}\text { Community } \\
\text { residents } \\
\text { (parent-child } \\
\text { ed.) }\end{array}$ & $\begin{array}{l}\text { Community } \\
\text { relations; } \\
\text { parent-child } \\
\text { education }\end{array}$ & $\begin{array}{l}\text { Community residents } \\
\text { (parent-child and } \\
\text { neighborhood } \\
\text { relations; societal care }\end{array}$ & $\begin{array}{l}\text { (Commercial and Social complete } \\
\text { inclusion) child care; family } \\
\text { restaurant; parent-child and } \\
\text { neighborhood relation }\end{array}$ & $\begin{array}{l}\text { Through societal service, } \\
\text { creates commercial } \\
\text { markets }\end{array}$ \\
\hline $\begin{array}{l}\text { Aurora } \\
\text { Social } \\
\text { Enterprise } \\
\text { Company }\end{array}$ & $\begin{array}{l}\text { Organic } \\
\text { produce } \\
\text { farming and } \\
\text { sale }\end{array}$ & $\begin{array}{l}\text { Households and } \\
\text { chain shores }\end{array}$ & $\begin{array}{l}\text { Mountain } \\
\text { indigenous worker } \\
\text { incomes and } \\
\text { employment }\end{array}$ & $\begin{array}{l}\text { Indigenous workers in } \\
\text { Mt. Ali area }\end{array}$ & $\begin{array}{l}\text { (Social) Organic farming skills and } \\
\text { coaching and education training } \\
\text { (commercial) Organic vegetables } \\
\text { sales }\end{array}$ & $\begin{array}{l}\text { Commercial activities } \\
\text { support the drive for } \\
\text { social service }\end{array}$ \\
\hline $\begin{array}{l}\text { Leezen } \\
\text { Organic } \\
\text { Chain }\end{array}$ & $\begin{array}{l}\text { Group } \\
\text { purchasing and } \\
\text { distribution of } \\
\text { organic } \\
\text { products }\end{array}$ & $\begin{array}{l}\text { Organic living } \\
\text { products mainly } \\
\text { for (religious } \\
\text { groups) } \\
\text { members }\end{array}$ & $\begin{array}{l}\text { Actualization of } \\
\text { life value } \\
\text { (religious concept) }\end{array}$ & $\begin{array}{l}\text { (Religious) members } \\
\text { and the general public }\end{array}$ & $\begin{array}{l}\text { (Social) Promotion of religious care } \\
\text { for life } \\
\text { (Commercial) Promotion organic } \\
\text { agriculture and group purchase and } \\
\text { sales }\end{array}$ & $\begin{array}{l}\text { Commercial activities } \\
\text { support the actualization } \\
\text { of life concept }\end{array}$ \\
\hline $\begin{array}{l}\text { Homemake } \\
\text { Union Corp }\end{array}$ & $\begin{array}{l}\text { Group purchase } \\
\text { and distribution } \\
\text { of Organic } \\
\text { products }\end{array}$ & $\begin{array}{l}\text { Organic living } \\
\text { products mainly } \\
\text { for the (co-op's) } \\
\text { members }\end{array}$ & $\begin{array}{l}\text { Organic } \\
\text { consumption and } \\
\text { healthy living }\end{array}$ & $\begin{array}{l}\text { Organic products for } \\
\text { regular households }\end{array}$ & $\begin{array}{l}\text { (Commercial and Social) Group } \\
\text { purchase and distribution } \\
\text { (Social) Disadvantaged women } \\
\text { entrepreneurship (distribution points } \\
\text { operation) }\end{array}$ & $\begin{array}{l}\text { The operation efficiency } \\
\text { from commercial } \\
\text { activities fulfills its } \\
\text { social concept. }\end{array}$ \\
\hline
\end{tabular}

Sources: Case Firms' Website as Table 1; field surveys; directors interview 


\section{Conclusion}

\subsection{Dual Operation System and Interrelations in Social Enterprise}

There are various types of interrelations between social value with a commercial target, and their extended management design. These interrelations should be formally understood for the mission to satisfy unmet social needs with limited social resources. Figure2. presents the internal dynamics of the dual-value operating system. The internal dual operation system and the interrelations can be summarized as follows:

A. Both the commercial interests and social value of social enterprises need, respectively, appropriate commercial operation system and social operation system to create production value.

B. The creation of commercial interests, just like regular businesses, needs to target its market demand, production development, and operation process to deliver value. By the same token, the creation of social value also need the practical social market demands, social product development, and social process to deliver its value.

C. Within an organization, its social value creating system and commercial interests system unavoidably face the interactive influence in the corresponding realms of strategic decision, marketing positioning, technology development, and process design, etc., which then determines the dynamic value equipping dual values.

Dees (1998) has stressed that the most critical distinguishing feature of social enterprises lies in innovation and social impact. The meaning of innovation is demonstrated in the systemic design of the social enterprise's operational model, which include social innovation and management innovation. Social innovation can be verified through the theory of social change and impact that social entrepreneurs uphold; management innovation is demonstrated in the planning of its business model.

D. On the strategic target level, the delivery and practice of social value can boost the social image of commercial output; correspondingly, the commercial operation capacity can help the sustainability and practice of social value. The interaction that exists between these two targets is purely complementary.

E. On the market positioning level, between social value market and business market, there exist complementary relationships of different types - namely, common markets, connected markets, and idea markets.

F. On the production technology level, the interaction relationships between social products and commercial products include: production line extension, forward integration of value, backward integration of value, and product diversification.

G. On the management process design level, the vertical combination in operation interaction also exists in the social value delivery process and business management process. The four interrelationship patterns are: forward integration of business process, backward integration of business process, joint process, and separated process.

H. Within social enterprises, the social and commercial systems form the internal dynamic relationships and value that are different in ideology yet interdependent in decision making and operation design.

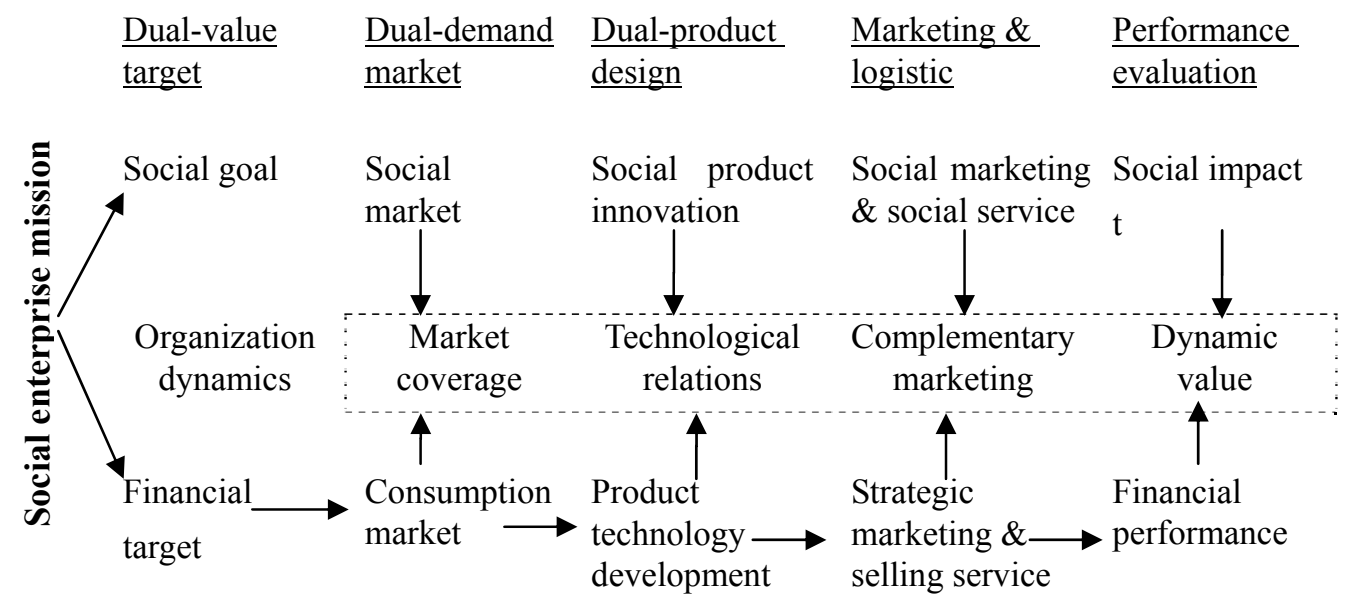

Figure 2. The internal dynamics of the dual-value operating system 


\subsection{Managerial Implications for Social Enterpreneurs}

Given the inherently colliding and contradictory nature of management targets of social enterprises, namely social impact versus financial benefits, smoothly executing subsequent functional strategies like marketing, product design, manufacturing, and supply requires the social entrepreneur to resolve these contradictions. This study found that there exist an interactive relationship between social value and commercial management; however, their relationships have mostly remained complementary or supportive, not dominant. By the same token, possibilities of market combination between their respective markets or supporting relations between upstream and downstream operations also exist as potential solutions.

Social entrepreneurs should actively seek to devise mutually beneficial approaches to integrate marketing communications with social value generated, as well as embed this message in product technology and its final manufacturing process so as to help social enterprises upgrade and reach efficiency in execution.

Based on our understanding of the dual-track operational model driven by the dual-value system in social enterprises, this research provides the following practical recommendations to current and would-be social entrepreneurs:

A. In the definition of its value concept, social enterprises need to integrate its social and commercial interests so that its employees have a clear understanding of its social service value and the people they serve. This would, during its business operation, provide important stability while clearly maintaining its social service direction, so that the pursuit of economic interests would not damage the significance of the attempted social value creation mission.

B. Given that both the social market and business market could have similar or identical target groups, social enterprises need to ensure that the overall marketing strategy integrates both messages, so that their respective promotional activities can simultaneously cover customers in the other market and enhance marketing efficiency.

C. While it is not necessary for social products and commercial products to be identical, they are mostly developed around similar physical commercial products. Based on this observation, social enterprises should design technology development policies that cover both kinds of products, rather than separate the realm of social and commercial product marketing.

D. Since dual-value goals social enterprises uphold will trigger respective value creation activities in marketing and technology development, it certainly is in need of an operation system that can deliver both values. If a system framework that covers the embedding of the operation process for both ends can be explicitly designed, the firm can then, in its daily operation, design the operation system that can obviously advance its social and economic utilities.

When social enterprises integrate the dual values and related management systems, the strategy, marketing, technology, management process, and organizational system involved will face resistance from the professionals they hire, including business managers and social workers for the conceptual differences in work skills and resource allocation. This friction could precipitate in challenges and conflicts during goal setting as well be manifested in push-backs during execution. To resolve such conflicts, social enterprises must be alert at all times, encouraging intra-organizational learning and communication, and maintaining "change management status" when the organization completes its internal transformation, so that dynamic adjustments can be made to ensure sustainability in its social mission, as well as management efficiency.

\section{References}

Alter, K. (2004). Social Enterprise Typology. Retrieved from http: //www.virtueventures.com/setypology.pdf

Alvord, S. H., Brown, L. D., \& Letts, C. W. (2004). Social Entrepreneurship and Social Transformation: An Exploratory Study. The Journal of Applied Behavioral Science, 40(3), 260-282. http://dx.doi.org/10.1177/0021886304266847

Austin, J. E., Stevenson, H. H., \& Wei-Skillern, J. (2006). Social and Commercial Entrepreneurship: Same, Different, or Both? Entrepreneurship Theory and Practice, 30(1), 1-22. http://dx.doi.org/10.1111/j.1540-6250.2006.00107

Budinich V., Reott K. M., \& Schmidt S. (2009). Hybrid Value Chains: Social Innovations and the Development of the Small Farmer Irrigation Market in Mexico. In Quelch, J. A., Rangan, V. K., Herrero, G., \& Barton, B. (eds.), Business solutions for the global poor: creating social and economic value (pp. 279-288). Jossey-Bass, January. 
Christie, M. J., \& Honig, B. (2006). Social Entrepreneurship: New Research Findings. Journal of World Business, 41, 1-5. http://dx.doi.org/10.1016/j.jwb.2005.10.003

Cohen, B., \& Winn, M. I. (2007). Market Imperfections, Opportunity and Sustainable Entrepreneurship. Journal of Business Venturing, 22, 29-49. http://dx.doi.org/10.1016/j.jbusvent.2004.12.001

Dees, J. G. (1998). Enterprising Nonprofit. Harvard Business Review, 76(1), 55-67.

Dees, J. G. (2001). The Meaning of "Social Entrepreneurship". Center for the Advancement of Social Entrepreneurship, Fuqua School of Business, Duke University. Retrieved from http://faculty.fuqua.duke.edu/centers/case/files/dees-SE.pdf

Dees, J. G. (2007). Taking Social Entrepreneurship Seriously. Society, 44(3), 24-31.

Defourny, J. (2001). Introduction: From third sector to social enterprise. In Carol Borzaga \& Jacques Defourny (eds.), The Emergence of Social Enterprise (pp. 1-28). London \& New York: Routledge.

Emerson, J., \& Bonni, S. (2003). The Blended Value Map: Tracking the Intersects and Opportunities of Economic, Social and Environmental Value Creation. The Blended Value Map Report-2003.

Frumkin, P. (2002). On Being Nonprofit: A Conceptual and Policy Primer. Cambridge: Harvard University Press.

Guclu, A., Dees, J. G., \& Anderson, B. B. (2002). The Process of Social Entrepreneurship: Creating Opportunities Worthy of Serious Pursuit. Retrieved from http://www.fuqua.duke.edu/centers/case/documents/dees_SE.pdf

Hansmann, H. B. (2003). The Role of Trust in Nonprofit Organization. In Anheier, H. K., \& Ben-Ner, A. (eds.), The Study of Nonprofit Enterprise: Theories and Approach (pp. 115-122). N.Y.: Kluwer Academic/Plenum Publishers.

Heckl, E., Peche, I., Aaltonen S., \& Stenholm, P. (2007). Study on Practices and Policies in the Social Enterprise Sector in Europer from http://ec.europa.eu/enterprise/entrepreneurship/coop/projects-studies/doc/country_fiches_es.pdf

Hu, J., \& Chang, T. Y. (2009). The Theme of Social Entrepreneurship: Social Innovation and Management Fusion. Journal of Entrepreneurship Research, 4(4), 85-105.

Hu, J., \& Chen, C. Y. (2009). The Essence, Tasks and Development of Social Enterprise. Journal of Entrepreneurship Research, 4(4), 1-28.

James, E. (1987). Economic Theories of the Nonprofit Sector: A Comparative Perspective. In Walter W. Powell (ed.), The Nonprofit Sector: A Research Handbook (pp. 21-290). New Haven: Yale University Press.

Katz, D., \& Kahn, R. L. (1978). The social psychology of organizations (2nd ed.). New York: Wiley.

Kuan, Y. (2006). Social Enterprise Development in Taiwan. Conference on Social Enterprises, Central Policy Unit and Commission on Poverty, The Government of Hong Kong Special Administrative Region.

Letts, C., Grossman, A., \& Ryan, W. (1999). High Performance Nonprofit Organizations: Managing Upstream for Greater Impact. New York: Wiley.

Mair J., \& Schoen, O. (2007). Successful social entrepreneurial business models in the context of developing economies. International Journal of Emerging Markets, 1(2), 54-68. http://dx.doi.org/10.1108/17468800710718895

Mair, J., \& Marti, I. (2006). Social entrepreneurship research: a source of explanation, prediction and delight. Journal of World Business, 41(1), 36-44. http://dx.doi.org/10.1016/j.jwb.2005.09.002

Meyer, C., \& Kirby, J. (2010). Leadership in the Age of Transparency. Harvard Business Review, April, 1-9.

Organization for Economic Co-operation and Development. (1999). Social Enterprises. Organization for Economic Co-operation and Development, Paris.

Peredo, A. M., \& McLean, M. (2006). Social Entrepreneurship: A Critical Review of the Concept. Journal of World Business, 41, 56-65. http://dx.doi.org/10.1016/j.jwb.2005.10.007

Sagawa, S., \& Segal, E. (2000). Common interest, common good: Creating Value through business and social partnership. California Management Review, 42(2), 1-24.

Salamon, L. M. (1990). The Nonprofit Sector and Government: The American Experience in Theory and Practice. In Anheier, H. K., \& Seibel, W. (eds.), The Third Sector: Comparative Studies of Nonprofit 
Organizations. New York: Walter de Gruyter.

Schumpeter J. (1934). The Theory of Economic De elopment. Cambridge: Harvard University Press.

Shane, S., \& Venkataraman, S. (2000). The Promise of Entrepreneurship as a Field of Research. Academy of Management Review, 25(1), 217-226. http://dx.doi.org/10.2307/259271

Shaw, E. (2004). Marketing in the Social Enterprise Context: Is it Entrepreneurial? Qualitative Market Research: An International Journal, 7(3), 194-205. http://dx.doi.org/10.1108/13522750410540209

Social Enterprise London. (2007). Social Enterprises in London: A Review of London Annual Business Survey (LABS) evidence. Greater London Authority.

Tang, K. L., Fung, H. L., Au, Kevin Y. F., Lee, James K. C., \& Ko, Lisanne S. F. (2008). Social Enterprise in Hong Kong: Toward a Conceptual Model. Final Report submitted to Central Policy Unit, The Government of the Hong Kong Special Administrative Region of the People's Republic of China. Retrieved from http://www.cpu.gov.hk

Weisbrod, Burton A. (1988). The Nonprofit Economy (pp. 25-27). Cambridge: Harvard University Press.

Will the Real Social Entrepreneur Please Stand Up? (2010). India Knowledge@Wharton. Retrieved from Knowledge@Wharton.upenn.edu

Zahra, S. A., Gedajlovic, E., Neubaum, D. O., \& Shulman, J. M. (2009). A Typology of Social Entrepreneurs: Motives, Search Process and Ethical Challenges. Journal of Business Venturing, 24, 519-532. http://dx.doi.org/10.1016/j.jbusvent.2008.04.007 